\title{
Uganda and Rwanda: Selected Issues
}

This Selected Issues paper for Uganda and Rwanda was prepared by a staff team of the International Monetary Fund as background documentation for the periodic consultation with the member countries. It is based on the information available at the time it was completed on December 15, 2008. The views expressed in this document are those of the staff team and do not necessarily reflect the views of the governments of Uganda and Rwanda, or the Executive Board of the IMF.

The policy of publication of staff reports and other documents by the IMF allows for the deletion of market-sensitive information.

Copies of this report are available to the public from

International Monetary Fund $\bullet$ Publication Services

700 19th Street, N.W. • Washington, D.C. 20431

Telephone: (202) 623-7430 • Telefax: (202) 623-7201

E-mail: publications@imf.org • Internet: http://www.imf.org

\section{International Monetary Fund \\ Washington, D.C.}





\title{
INTERNATIONAL MONETARY FUND
}

\section{UGANDA AND RWANDA}

\author{
Selected Issues \\ Prepared by Zuzana Murgasova, Michael Gorbanyov, \\ Manrique Saenz, and Yuri Sobolev. \\ Approved by the African Department
}

December 15, 2008

Contents

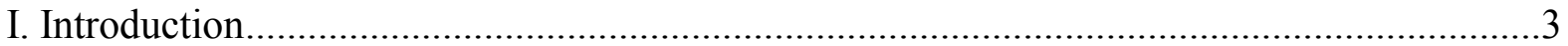

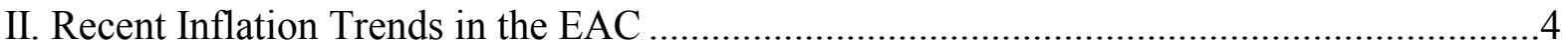

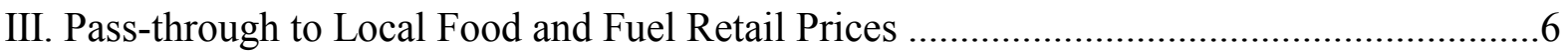

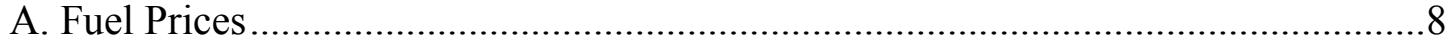

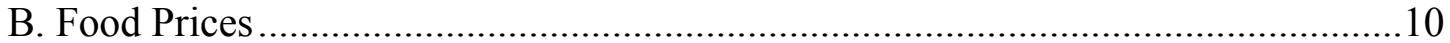

IV. How Much Inflation Can be Explained with World Oil and Food Prices: Econometric

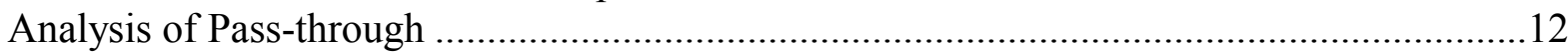

A. The Rationale for Econometric Analysis ..............................................................12

B. Econometric Estimation of the Overall Pass-through to Inflation ...........................12

C. Tracking Individual Pass-through Channels ........................................................14

D. How Much Inflation Arises From the Commodity Prices Shock? ............................16

V. Is There Scope for Domestic Policies to Mitigate the Pass-through? First- and Second-

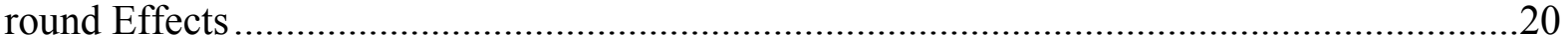

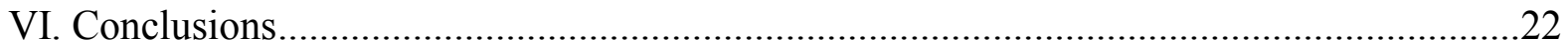

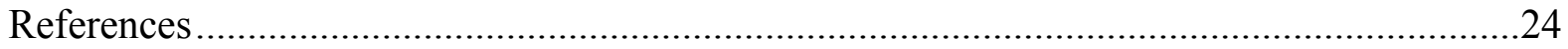

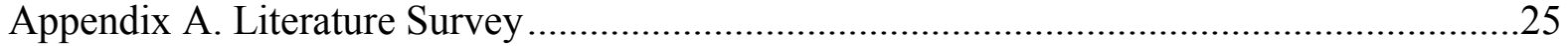

Appendix B. Methodology of the Econometric Analysis .......................................................26 
Tables

1. Domestic Petroleum Pricing in 2006 ....

2. EAC Countries: Imports of Cereals in Relation to Total Food Imports and Domestic

Production. 10

3. Pass-through from World Food and Fuel Prices into Inflation in EAC countries ...............13

4. EAC Countries: Share of Food and Fuel in Imports and Consumption Basket..................13

5. Pass-through from World Food and Fuel Prices into Inflation Components......................15

6. Estimated Contribution of World Food and Oil Prices to Inflation in EAC Countries .......17

7. Contribution of World Oil and Food Prices to 12-Month Inflation and First- and Secondround Effects Decomposition ..................................................................................22

A1. Summary of Pass-through Estimates Obtained from Various Model Specifications .......29

A2. Impact of the World Food and Fuel Prices on Money and Exchange Rate in EAC

Countries

Figures

1. Headline Inflation .............................................................................................

2. International Food and Oil Prices .........................................................................

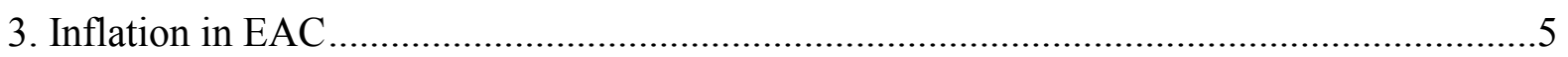

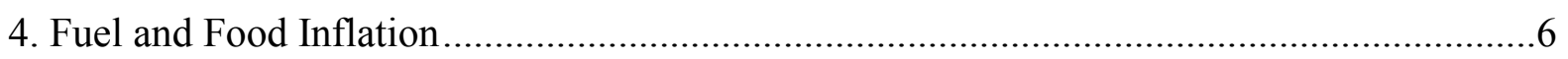

5. Ratio of Domestic Price Change to WEO Price Change in Local Currency ........................7

6. WEO Fuel and Food Price Changes, Cumulative, in U.S. Dollars and Local Currencies.....7

7. Rwanda: Breakdown of Retail Gasoline Price...................................................................8

8. Retail Pump Gasoline Prices.................................................................................. 9

9. Maize and Rice Retail Prices in the Largest EAC Countries.............................................11

10. Pass-through Channels from World Food and Oil Prices to Inflation ..............................14

11. World Food and Oil Prices and end-June Inflation in EAC Countries .............................18

12. Contribution to Inflation of World Food and Oil Prices and Other Factors .....................19

Boxes

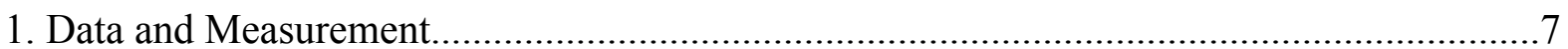




\section{Impact of Rising International Food and Fuel Prices on Inflation in EAC Countries ${ }^{1}$}

\section{INTRODUCTION}

The sharp increase in food and fuel prices worldwide in the past few years has fueled inflationary pressures in the countries of the East African Community (EAC). While developments in world commodity prices are clearly beyond the control of any single EAC country, prolonged periods of high inflation could jeopardize the area's hard-won gains in macroeconomic stability and poverty reduction and could undermine economic growth. Policy actions may therefore be necessary to mitigate the adverse economic effects.

To help guide the policy response, this paper attempts to disentangle the impact on inflation in the EAC arising from international food and oil prices from the effects of other factors. It seeks to identify factors that best characterize the pass-through in each country, recognizing differences in market structure, regulatory regime, and policy response.

In what follows, Section II reviews recent inflation trends in the EAC countries and Section III looks in more detail at the evolution of world and local prices for food and fuel and studies factors that link them. Section IV presents econometric estimates of the impact of world commodity prices on domestic inflation. Section V makes a distinction between the first and second round effects of world food and oil prices on domestic inflation and discusses the policy implications. Finally, Section VI concludes.

\footnotetext{
${ }^{1}$ Prepared by Zuzana Murgasova, Michael Gorbanyov, Manrique Saenz, and Yuri Sobolev. This version benefited from helpful suggestions from Andy Berg and Rafael Portillo. Alijohn Ghassabeh provided excellent research assistance.
} 


\section{RECENT INFLATION TRENDS IN THE EAC}

Inflation has been on the rise across all of sub-Saharan Africa in 2008. For EAC countries as a group, annual headline inflation rose from 4 percent at the end of 2006 to 12 percent by mid-2008 (Figure 1). Meanwhile, measured by the U.S. dollar-denominated World Economic Outlook (WEO) indices, world prices for food have increased by about half and for fuel about two-thirds since January 2006 (Figure 2). Rising global commodity prices have thus largely been perceived as the primary factor behind the recent acceleration of headline inflation in the EAC (Figure 3). Inflation remained high in recent months despite a decline in world commodity prices that began in mid-2008.

Figure 1. Headline Inflation (percent, period average)

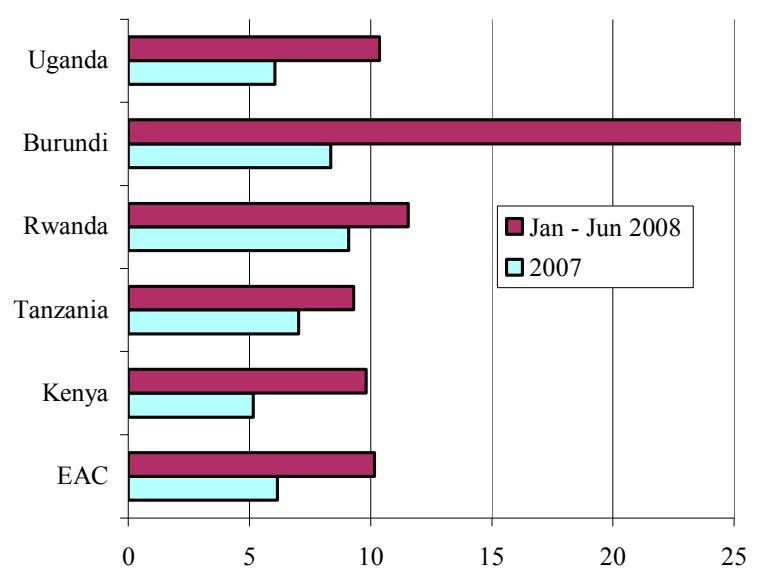

Source: Country authorities; and IMF staff estimates.
Figure 2. International Food and Oil Prices

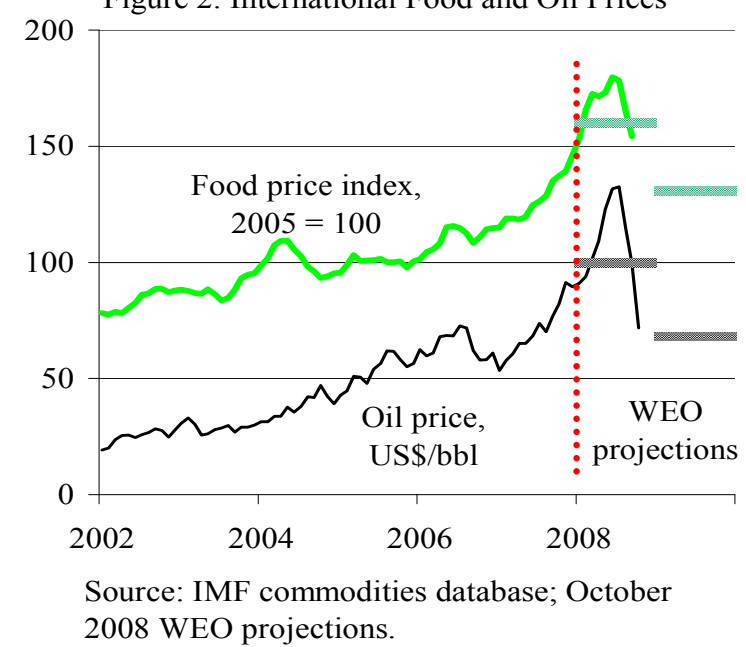

The pass-through of world fuel and food prices into local prices in the EAC countries is analyzed here in terms of the effect of world commodity prices (i) on domestic retail prices of fuel and food, and (ii) on overall domestic CPI inflation. 
Figure 3. Inflation in EAC (percent, 12 months change)
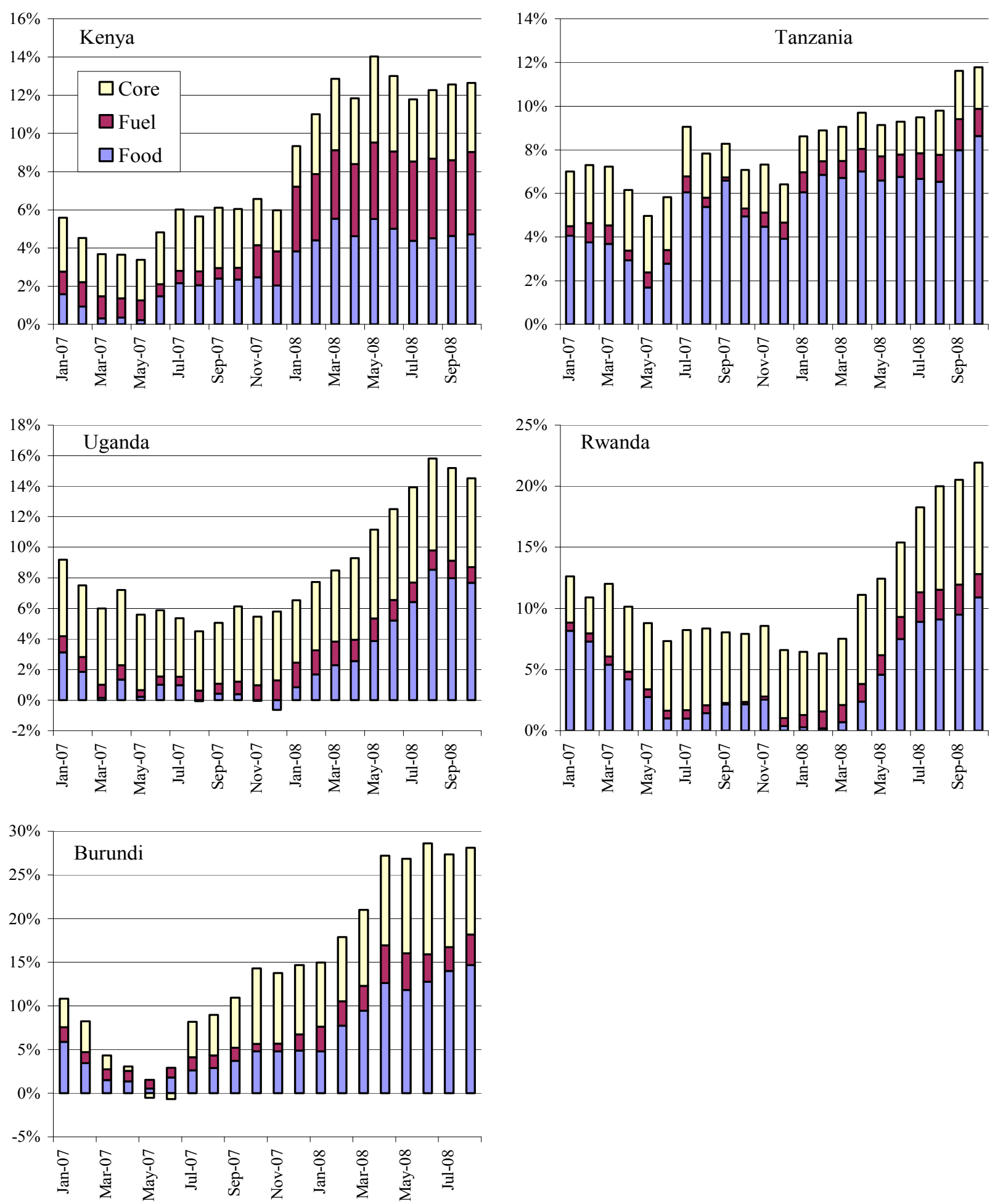

Source: Country authorities; and IMF staff estimates. 


\section{Pass-through to Local Food and Fuel Retail Prices}

Retail food and fuel prices (in local currency) in the EAC countries have accelerated in line with developments in global commodity markets, but their increase has been smaller than the increase in international prices (Figure 4). In fact, except in Rwanda, domestic food and fuel retail prices increased by less than half the increase in world prices as expressed in local currency (Figure 5). ${ }^{2}$ Fuel prices have shown a higher pass-through than food, except in Kenya, which has some domestic refining capacity.

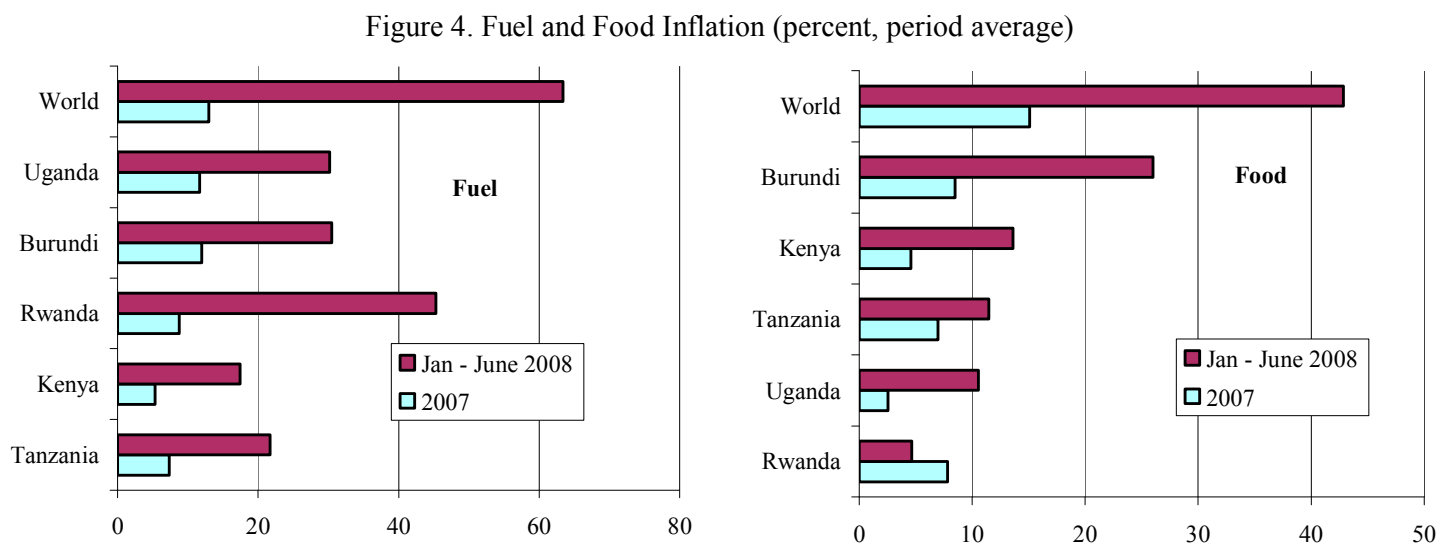

Source: WEO; country authorities; and IMF staff estimates.

Note: World price increase in U.S. dollars; EAC countries in domestic currency. Kenya data through March 2008.

Exchange rate developments have affected the price pass-through (Figure 6). With international commodity prices mostly denominated in U.S. dollars, in Kenya and Uganda nominal appreciation of domestic currencies against the U.S. dollar in 2007 and the first half of 2008 has provided some relief from higher international prices. Conversely, the currency depreciation in Burundi has exacerbated the impact of rising world prices. The exchange rate impact in Rwanda and Tanzania has been negligible.

\footnotetext{
${ }^{2}$ Pass-through in this section is measured as the ratio of the percent increase in the domestic prices of fuel and food and the percent increase in the WEO prices, both expressed in local currency. The ratio is expressed as a percentage.
} 


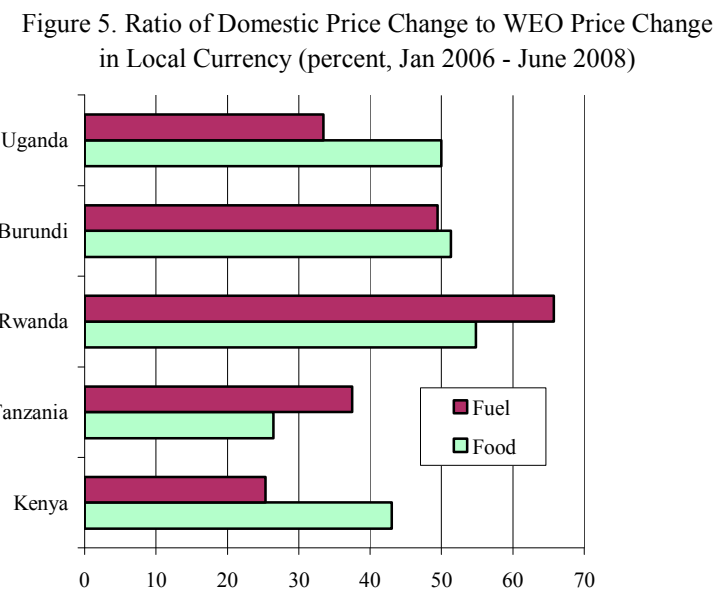

Source: WEO, country authorities, and Fund staff estimates. Note: Kenya data through March 2008.

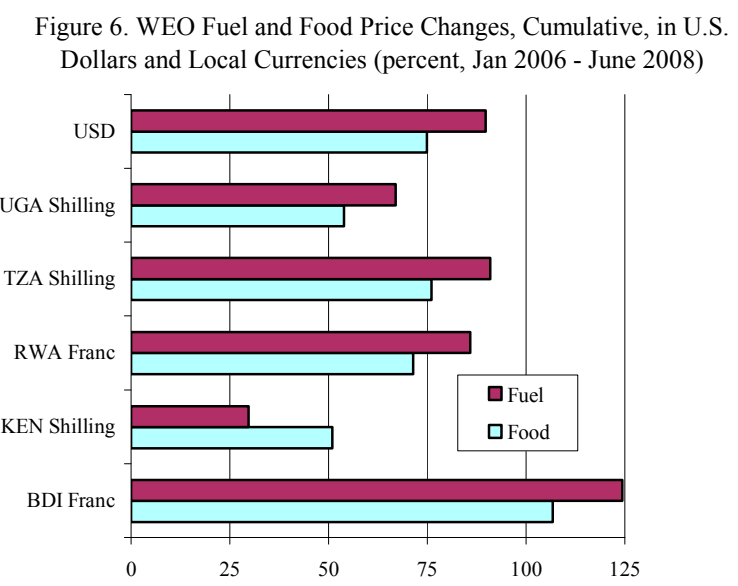

Source: WEO, country authorities, and Fund staff estimates. Note: Kenya data through March 2008.

\section{Box 1. Data and Measurement}

This study adopts the CPI category definitions reported by country authorities, which are not uniform. For example, the food component includes beverages in Kenya, Rwanda, and Burundi, and the fuel category includes power and utilities in Kenya, Tanzania, and Uganda.

The weight in the CPI of imported foods-which are directly affected by rising world food prices - is not known for most EAC countries, though in Rwanda it represents about 10 percent of the total consumption basket. The standard CPI subcategory of "food" used in the analysis therefore overstates the true pass-through. Also, the consumption weights of individual food products used in the World Economic Outlook (WEO) food price index vary from those used in EAC countries. This is evident from the Kenya data, where the actual pass-through for food prices would be even lower if the standard WEO food index were weighted

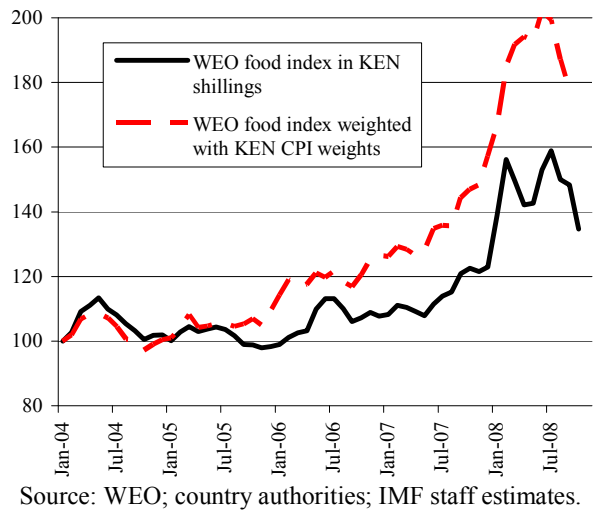
by the Kenya CPI weights.

\section{Country and sector factors}

Country- and sector-specific factors can introduce a wedge between international and domestic prices of the same commodity, among them:

- Domestic cost structure. A reduction in the initially large local-cost components, profits and margins can help absorb (up to a point) the rising costs of a commodity.

- Market fragmentation. Small-scale farming and inadequate infrastructure result in domestic markets that are fragmented and partially insulated from international markets, which limits the pass-through of international price movements. 
- Government regulatory policies and market interventions. Taxation, trade restrictions on exports, and the use of strategic grain reserves can mitigate the impact of rising world prices on domestic retail prices.

These factors are now explored for food and fuel prices.

\section{A. Fuel Prices}

With no domestically-extracted oil, EAC countries rely fully on imports of refined fuel products (except for Kenya, which imports about half of its fuel in the form of crude oil for local processing). Market fragmentation is therefore not an issue with respect to fuel, which can be considered a perfectly homogenous good. The primary factor behind the limited pass-through of fuel prices observed is therefore the high domestic component of retail fuel prices in relation to the wholesale import price (fob). This domestic component includes taxes (import duties and VAT or excise taxes), transportation,

Figure 7. Rwanda: Breakdown of Retail Gasoline Price (Rwanda francs per liter)

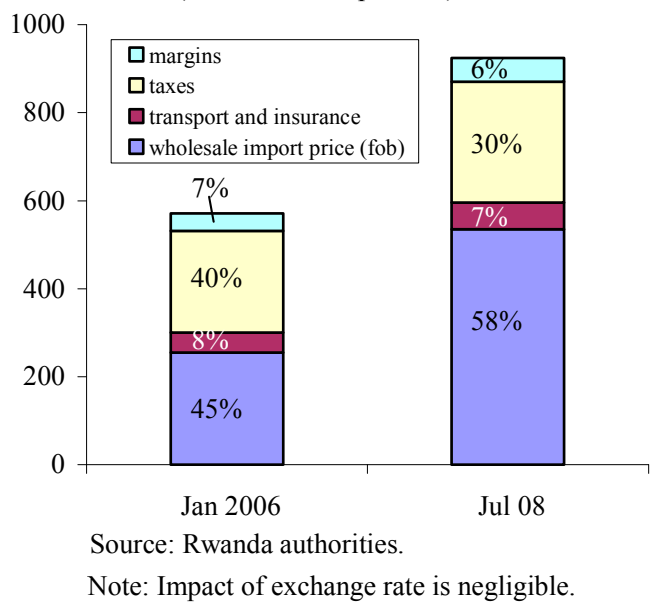
and profit margins, which together account for 40 to 50 percent of the retail price (Figure 7). This cost structure offers scope to contain retail price increases either by changing the effective tax rates, which limits the increase in nominal taxes (Burundi, Rwanda) or by applying specific taxes that are set in nominal terms (Figure 8). Similarly, in some countries, the initially high profit margins of importers allowed them to absorb some of the cost increases. While transportation costs increased somewhat because of higher fuel prices, the wage and fixed components helped

\begin{tabular}{|c|c|c|c|c|}
\hline \multirow{3}{*}{$\begin{array}{l}\text { Country } \\
\text { name }\end{array}$} & \multirow{3}{*}{$\begin{array}{l}\text { Country net } \\
\text { oil importer }(M) \\
\text { or exporter }(X)\end{array}$} & \multicolumn{3}{|c|}{ Regime } \\
\hline & & \multirow{2}{*}{$\begin{array}{l}\text { Liberalized (L)/ } \\
\text { Controlled (C) }\end{array}$} & \multicolumn{2}{|c|}{ If controlled: } \\
\hline & & & $\begin{array}{l}\text { Automatic }(\mathrm{A}) / \\
\text { Ad-hoc }(\mathrm{AH}) \\
\text { Adjustments? }\end{array}$ & $\begin{array}{l}\text { If automatic: } \\
\text { Frequency of } \\
\text { adjustment }\end{array}$ \\
\hline Burundi & $M$ & $\mathrm{C}$ & $\mathrm{AH}$ & \\
\hline Kenya & M & L & & \\
\hline Rwanda & $M$ & C & $\mathrm{AH}$ & Monthly reviews \\
\hline Tanzania & $M$ & $\mathrm{~L}$ & & \\
\hline Uganda & $\mathrm{M}$ & $\mathrm{L}$ & & \\
\hline
\end{tabular}
mitigate the increase in this cost element. Finally, even though retail fuel prices in most EAC countries are not regulated, moral suasion may have been used in some countries to limit the increase in pump prices. 
Figure 8. Retail Pump Gasoline Prices

(U.S. dollars per liter)
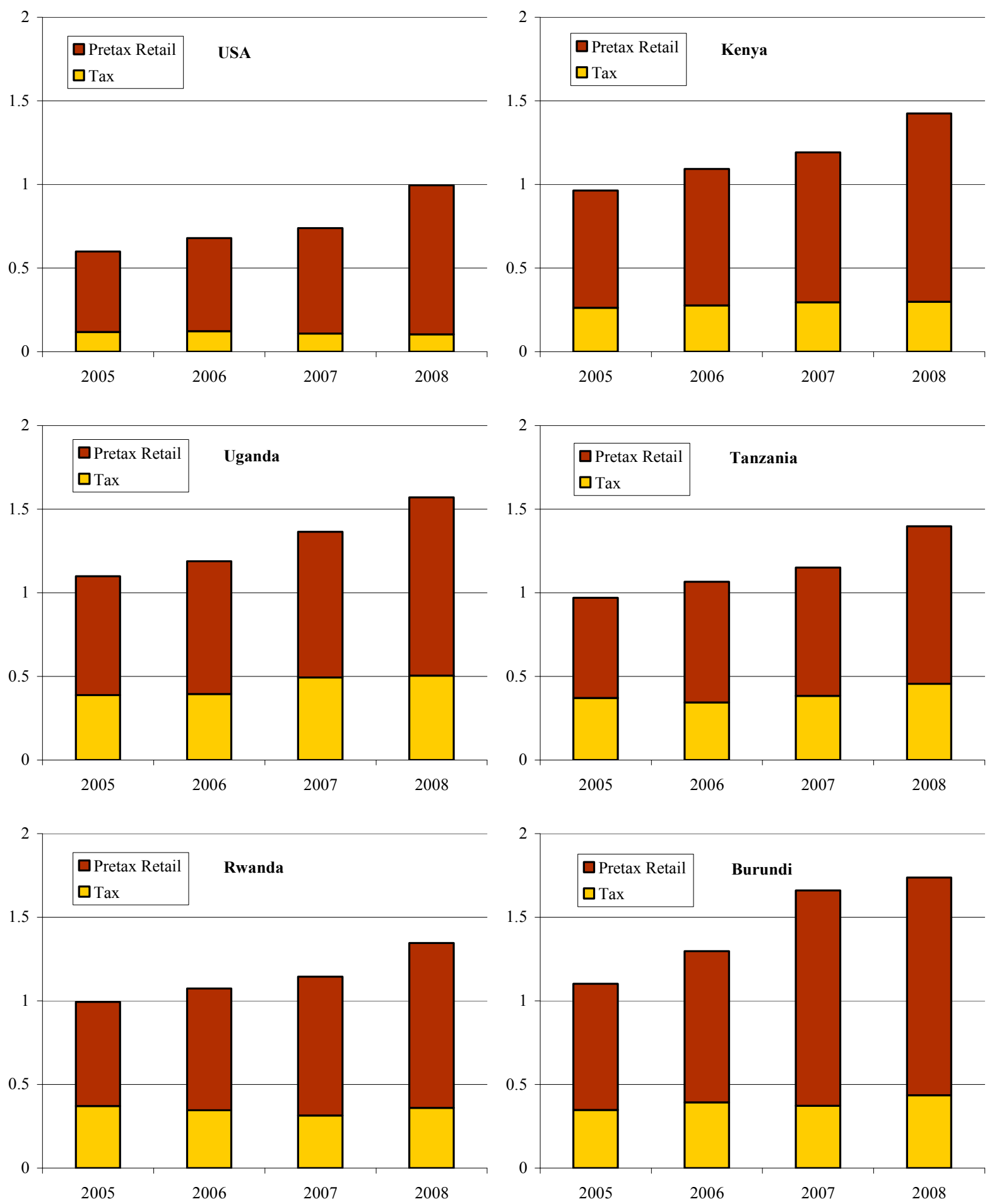

Source: Country authorities.

January-June average for 2008. 


\section{B. Food Prices}

Unlike in the case of fuel, EAC countries are major agricultural producers, with agriculture accounting for 20 to 40 percent of their GDP. The two most important factors limiting the pass-through of world food commodities are therefore the high degree of self-sufficiency in the production of the main tradable food commodities and their relative insulation from international markets. Barring adverse weather, the EAC as a region is largely self-sufficient, especially in the production of maize, which on average comprises less than 5 percent of total food imports (Table 2).

Table 2: EAC Countries: Imports of Cereals in Relation to Total Food Imports and Domestic Production (Percent, 2001-06 average)

\begin{tabular}{lccccc}
\hline & \multicolumn{3}{c}{ Maize } & & \multicolumn{2}{c}{ Rice } \\
\cline { 2 - 3 } \cline { 5 - 6 } & Food imports & Domestic production & & Food imports & Domestic production \\
\hline Kenya & 4.2 & 4.7 & & 8.4 & 372.6 \\
Tanzania & 4.8 & 3.0 & & 7.7 & 19.2 \\
Uganda & 4.0 & 2.7 & & 6.4 & 38.7 \\
Rwanda & 4.1 & 3.4 & & 8.7 & 50.9 \\
\hline
\end{tabular}

Sources: Country authorities, UNCTAD TRAINS

The segmentation of local markets stems from the predominantly small-scale subsistenceoriented farming in the EAC countries and the poor transport infrastructure. While there are quasi-public crop-marketing boards managing strategic grain reserves, they mainly smooth domestic consumption to ensure food security rather than take into account commercial considerations. Thus, even prices of homogenous tradable products like maize have responded only mildly to global market trends. Also, under the EAC Customs Union common external tariff, maize, rice, wheat and wheat flour, sugar, and milk are among the products on the so-called sensitive list that are subject to import duties ranging from 35 to 75 percent. Together with the export bans countries like Tanzania have temporarily imposed to increase domestic availability of maize, the high protective tariff rates further insulate EAC countries from international commodities markets. As a result, about 60 percent of recorded exports of maize and rice from individual member countries stay within the EAC. The temporary suspension or reduction of import duties for cereals introduced in Tanzania and Kenya has also helped to limit the pass-through to domestic prices.

Consequently, domestic food prices are mostly determined by the weather conditions affecting local agriculture and by the cost of distribution primarily related to the price of fuel. This is evident from comparing domestic production and recorded foreign trade data and prices for maize and rice, the two EAC food staples. The price of rice, which is more importdependent, is more closely correlated with the international price, and the price of thinlytraded maize correlates more closely with domestic supply conditions (Figure 9). 
Figure 9. Maize and Rice Retail Prices in the Largest EAC Countries (percent change)
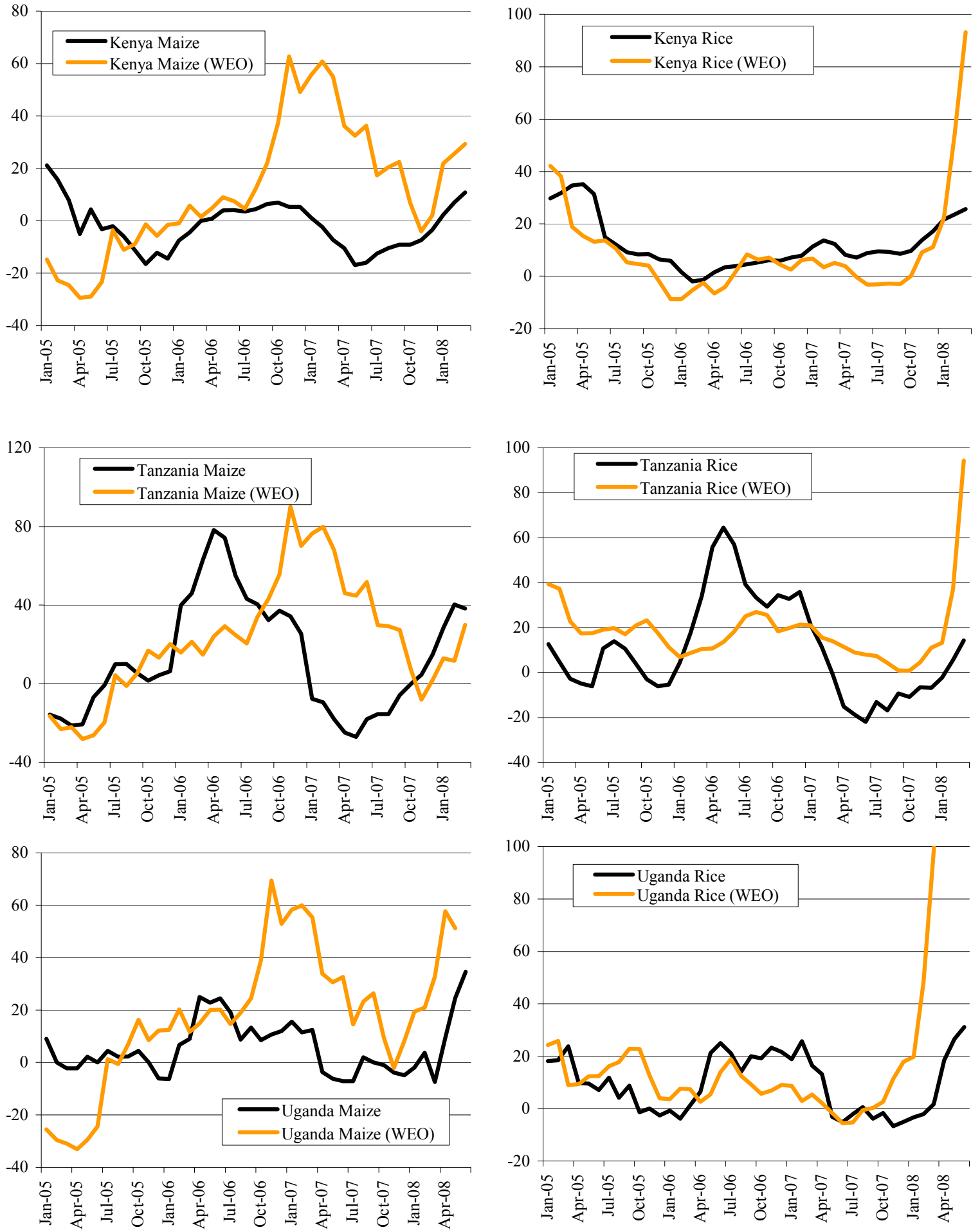

Source: Country authorities; and IMF staff estimates. 


\section{How Much Inflation Can be Explained With World Oil and Food Prices: ECONOMetric Analysis of PAss-Through}

\section{A. The Rationale for Econometric Analysis}

Because inflation in each country depends on a variety of factors, disentangling the actual impact of world food and oil prices can be challenging. Monetary policy and inflation expectations, economic activity (including in agriculture), exchange and interest rates, and other domestic and international factors can all affect inflation. Together these factors may have more impact than the direct contribution from world food and oil prices. It is therefore necessary to construct a model that captures the impact of international food and fuel prices. (Appendix A provides a summary of the relevant literature; the econometric methodology is detailed in Appendix B.)

\section{B. Econometric Estimation of the Overall Pass-through to Inflation}

The econometric analysis confirms that world oil and food prices do have an important effect on headline inflation in the EAC, although the effect varies significantly from country to country (Table 3). In three out of five countries and for the EAC on average the pass-through coefficient for food prices is higher than for oil, which is broadly in line with the much higher weights food items have in CPIs. An increase in world food prices by 10 percent contributes on average about 0.7 percentage points to headline inflation in the EAC countries; a 10 percent increase in world oil prices contributes about 0.4 percentage points. For most countries, the pass-through from oil into inflation was highly significant, the pass-through from food less so.

The estimated pass-through coefficients show the average impact of world food and oil prices on inflation during the sample period (1997 to early 2008). These results reflect the typical (average) policy response of each country to food and oil price shocks during this time. In certain years the pass-through may have been lower or higher than the average for the 10 years, in part because of shifts in policy. 
Table 3. Pass-through from World Food and Fuel Prices into Inflation in EAC countries.

(Percentage points ${ }^{1}$ )

\begin{tabular}{llllllr} 
& Burundi & Kenya & Rwanda & Tanzania & Uganda & EAC average $^{2}$ \\
\hline World food price & 0.75 & $1.11^{* *}$ & $1.03^{*}$ & $0.38^{3}$ & 0.25 & 0.71 \\
World oil price & $0.84^{* * *}$ & $0.37^{* * * *}$ & $0.29^{* *}$ & $0.18^{3}$ & $0.59 * * *$ & 0.37 \\
\hline
\end{tabular}

Source: IMF staff estimates.

${ }^{1}$ Contribution of 10 percent increase in each variable to the headline inflation. For Tanzania, estimated using VECM model. For other countries, estimated using VAR model with world food and oil price as exogenous variables.

${ }^{2}$ Calculated as weighted average, using the 2005 nominal GDP in US dollar terms as weights.

${ }^{* * * *}$ Indicates significance at 90 percent, ${ }^{* * *}$ significance at 80 percent,

** Indicates significance at 70 percent, * significance at 60 percent.

${ }^{3}$ Statistical significance level not available.

These results are broadly in line with the relative importance of food and fuel for EAC economies. The high estimates of pass-through for food is consistent with the large weight of food in the CPI basket, which range from 27 percent in Uganda to 56 percent in Tanzania (Table 4). Food imports also account for 10 to 15 percent of EAC member imports. In contrast, fuel is a relatively minor component of direct consumption, but serves as an input into production and distribution and accounts for up to a fifth of total imports. The stronger pass-through from world food prices compared to world oil prices is also consistent with findings of other studies. ${ }^{3}$

Table 4. EAC Countries: Share of Food and Fuel in Imports and Consumption Basket (Percent)

\begin{tabular}{lcccc}
\hline & \multicolumn{2}{c}{ Current weight in CPI } & \multicolumn{2}{c}{$\begin{array}{c}\text { Share in total Imports } \\
\text { 2001-06 average }\end{array}$} \\
\hline Food & Fuel & Food & Fuel \\
Kenya & 50.5 & 4.2 & 11.1 & 21.3 \\
Tanzania & 55.9 & 8.5 & 13.4 & 17.2 \\
Uganda & 27.2 & 4.9 & 14.7 & 15.6 \\
Rwanda & 37.1 & 2.9 & 13.6 & 14.3 \\
Burundi & 51.8 & 5.3 & 13.4 & 11.4 \\
\hline
\end{tabular}

Source: Country authorities, UNCTAD TRAINS

Note: Fuel category for Kenya, Tanzania, and Uganda includes power and utilities.

\footnotetext{
${ }^{3}$ Regional Economic Outlook: Western Hemisphere, Spring 2008; World Economic Outlook, Fall 2008.
} 


\section{Tracking Individual Pass-through Channels}

The impact of world fuel and food prices can pass into inflation through different channelsespecially local food, fuel, and core prices. ${ }^{4}$ For instance, world fuel prices affect domestic fuel and transportation prices directly and core inflation indirectly through their impact on the input costs for all other products. These channels are represented in Figure 10 and their estimated strength is shown in Table 5.

Figure 10. Pass-through Channels from World Food and Oil Prices to Inflation ${ }^{1}$

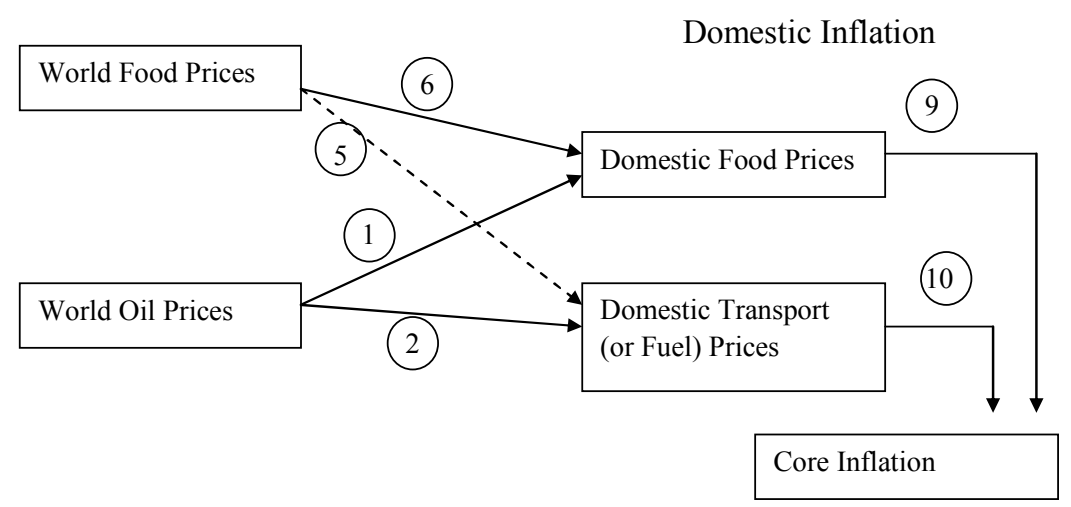

${ }^{1}$ Captured by the set of three VAR models for each EAC country. Numbering of channels matches the numbering of lines in Table 5, presenting the numerical results.

\footnotetext{
${ }^{4}$ In this exercise the headline CPI is decomposed into these additive and mutually exclusive components.
} 
Table 5. Pass-through from World Food and Fuel Prices into Inflation Components

(Percentage points ${ }^{1}$ )

\begin{tabular}{|c|c|c|c|c|c|c|}
\hline & Burundi & Kenya & Rwanda & Tanzania & Uganda & ${\text { EAC } \text { average }^{2}}^{2}$ \\
\hline \multicolumn{7}{|l|}{ From world food price } \\
\hline 1. To domestic food & $3.32 * * *$ & $2.09 * * *$ & 2.41 * & 0.28 & 0.32 & 1.25 \\
\hline 2. To domestic transport ${ }^{3}$ & 0.85 & -0.39 & $1.13^{* *}$ & 0.04 & 0.31 & -0.02 \\
\hline 3. To core inflation ${ }^{4}=(1 * 9+2 * 10)$ & -0.48 & 0.12 & 0.41 & -0.05 & 0.12 & 0.07 \\
\hline 4. Total $^{5}$ & 1.56 & 1.09 & 1.22 & 0.14 & 0.20 & 0.65 \\
\hline \multicolumn{7}{|l|}{ From world oil prices } \\
\hline 5. To domestic food & $0.88^{* *}$ & 0.25 & 0.18 & -0.12 & $1.16^{* * * *}$ & 0.34 \\
\hline 6. To domestic transport ${ }^{3}$ & $2.30 * * * *$ & $1.30^{* * * *}$ & $0.45^{* * * *}$ & $0.35^{* * *}$ & $0.27 *$ & 0.78 \\
\hline 7. To core inflation ${ }^{4}=\left(5^{*} 9+6^{*} 10\right)$ & -0.78 & 0.16 & 0.15 & 0.19 & 0.33 & 0.19 \\
\hline 8. Total $^{5}$ & 0.24 & 0.25 & 0.19 & 0.03 & 0.55 & 0.25 \\
\hline \multicolumn{7}{|l|}{ Memorandum: } \\
\hline \multicolumn{7}{|c|}{ Pass-through from domestic food and transport prices into core inflation } \\
\hline 9. Domestic food price & -0.65 & 0.75 & 0.10 & -2.35 & 2.60 & \\
\hline 10. Domestic transport price & -3.15 & 1.10 & 3.37 & 4.66 & 1.12 & \\
\hline \multicolumn{7}{|c|}{ Weights of components in the CPI basket } \\
\hline Food & 51.8 & 50.5 & 37.1 & 55.9 & 27.2 & \\
\hline Transport $^{3}$ & 5.3 & 4.2 & 9.9 & 9.7 & 12.8 & \\
\hline Core inflation & 42.9 & 45.3 & 53.0 & 34.4 & 60.0 & \\
\hline
\end{tabular}

Source: IMF staff estimates.

${ }^{1}$ Contribution of 10 percent increase in each variable to the growth rate of inflation component.

${ }^{2}$ Calculated as weighted average, using the 2005 nominal GDP in US dollar terms as weights.

${ }^{3}$ Fuel prices for Kenya.

${ }^{4}$ Calculated as "second-round" pass-through effect.

${ }^{5}$ Calculated as sum of pass-through to domestic transport, domestic food, and core inflation multiplied by their weights in the total CPI basket.

**** Indicates significance at 90 percent, ${ }^{* * *}$ significance at 80 percent, ${ }^{* *}$ significance at 70 percent,

* significance at 60 percent. Significance reported only for pass-through from world oil and food prices into the domestic food and transport prices.

The results suggest that the pass-through from world food to domestic food prices is particularly high in Burundi, Kenya, and Rwanda (a 10 percent increase in world prices contributed 2.1 to 3.3 percentage points to domestic food prices indices in these countries, with high statistical significance) but is weaker in Tanzania and Uganda (about 0.3 percentage points).

The pass-through from world oil prices to domestic transport or fuel prices appears to be the strongest in Burundi and Kenya (a 10 percent increase in world prices contributes about 2.3 percentage points to local transport inflation in Burundi and about 1.3 percentage points to fuel price inflation in Kenya, with high statistical significance). For Rwanda, Tanzania, and Uganda, this impact is lower.

The contribution of world food and oil prices to core inflation is also estimated. The impact of world oil prices on core inflation is strongest in Rwanda; the estimates for the other 
countries are close to zero or even, unexpectedly, negative. The contribution of world food prices to core inflation is highest in Uganda.

Based on the estimates of pass-through via these channels, the overall contribution to headline inflation is calculated using the weight of each component in the CPI basket. The overall results confirm that the pass-through from world to local food prices is the most important factor of inflation, followed by the impact of world oil prices on domestic transportation. ${ }^{5}$

\section{How Much Inflation Arises From the Commodity Prices Shock?}

The estimated pass-through coefficients can be applied either to study past inflation or to make inflation projections. For the past, we multiply actual changes in world food and oil prices by the pass-through coefficients and thus calculate their contribution to inflation in EAC countries over a given period. For the projections, we take the World Economic Outlook (WEO) projections of food and oil prices and multiply them by the same pass-through coefficients. ${ }^{6}$

The calculations suggest that in 2008 the contribution of world food and oil prices to average annual inflation in EAC is about 3.3 percentage points - more than twice than in 2007 (Table 6). As with average inflation, the contribution of world oil and food prices to 12-month EAC inflation increased from 0.9 percentage points in June 2007 to 5.7 in June 2008, which explains more than two-thirds of the observed increase in headline inflation (Figure 11). The ongoing sharp world food and oil price decline is expected to persist in 2009, implying that the pass-through will become negative and could reduce up to 2.5 percentage points from inflation in EAC (Table 6).

\footnotetext{
${ }^{5}$ The estimated pass-through of world food and oil prices to the headline inflation in this approach differs somewhat from the estimates obtained from single-VAR approach (Table 3). This may indicate that the more detailed approach, which focuses on transmission channels, may not capture fully all the second-round effects of passthrough (see Appendix B for methodology).

${ }^{6}$ These projections assume no change in the pass-through coefficients, in the absence of major structural changes in the EAC economies or major shifts in government policies on accommodating the impact of world price shocks.
} 
Table 6. Estimated Contribution of World Food and Oil Prices to Inflation in EAC Countries (Percentage points)

\begin{tabular}{|c|c|c|c|c|c|c|}
\hline & Burundi & Kenya & Rwanda & Tanzania & Uganda & EAC average ${ }^{1}$ \\
\hline \multicolumn{7}{|c|}{ Estimated contribution to average inflation, $2007^{3}$} \\
\hline Headline inflation ${ }^{4}$ & 8.3 & 9.8 & 9.1 & 7.0 & 6.1 & 8.2 \\
\hline World food price & 1.1 & 1.7 & 1.6 & 0.6 & 0.4 & 1.1 \\
\hline World oil price & 0.9 & 0.4 & 0.3 & 0.2 & 0.6 & 0.4 \\
\hline Total contribution & 2.0 & 2.1 & 1.9 & 0.8 & 1.0 & 1.5 \\
\hline Share of inflation & 24.4 & 21.3 & 20.7 & 11.0 & 16.6 & 18.1 \\
\hline Other factors & 6.3 & 7.7 & 7.2 & 6.3 & 5.1 & 6.7 \\
\hline \multicolumn{7}{|c|}{ Estimated contribution to projected average inflation, $2008^{5}$} \\
\hline Projected inflation ${ }^{4}$ & 23.7 & 25.0 & 15.0 & 9.3 & 12.1 & 17.3 \\
\hline World food price & 1.9 & 2.9 & 2.7 & 1.0 & 0.6 & 1.8 \\
\hline World oil price & 3.4 & 1.5 & 1.2 & 0.7 & 2.4 & 1.5 \\
\hline Total contribution & 5.3 & 4.4 & 3.8 & 1.7 & 3.0 & 3.3 \\
\hline Share of inflation & 22.4 & 17.4 & 25.4 & 18.5 & 25.0 & 19.2 \\
\hline Other factors & 18.4 & 20.6 & 11.2 & 7.6 & 9.1 & 14.0 \\
\hline \multicolumn{7}{|c|}{ Estimated contribution to projected average inflation, $2009^{5}$} \\
\hline Projected inflation ${ }^{4}$ & 11.2 & 6.5 & 12.0 & 6.6 & 10.0 & 7.6 \\
\hline World food price & -1.4 & -2.0 & -1.9 & -0.7 & -0.5 & -1.3 \\
\hline World oil price & -2.7 & -1.2 & -0.9 & -0.6 & -1.9 & -1.2 \\
\hline Total contribution & -4.1 & -3.2 & -2.8 & -1.3 & -2.3 & -2.5 \\
\hline Other factors & 15.3 & 9.7 & 14.8 & 7.9 & 12.3 & 10.1 \\
\hline
\end{tabular}

Source: WEO; IMF staff estimates.

${ }^{1}$ Calculated as weighted average, using the 2005 nominal GDP in US dollars as weights.

${ }^{2}$ Contribution of 10 percent increase in each variable to the headline inflation.

${ }^{3}$ Multiples of the passthrough coefficients and actual increase in world food and oil prices.

${ }^{4}$ Actual and projected annual average inflation (most recent data available).

${ }^{5}$ Estimated using the increase in world food and oil prices projected by WEO for 2008-09. 
Figure 11. World Food and Oil Prices and end-June Inflation in EAC Countries
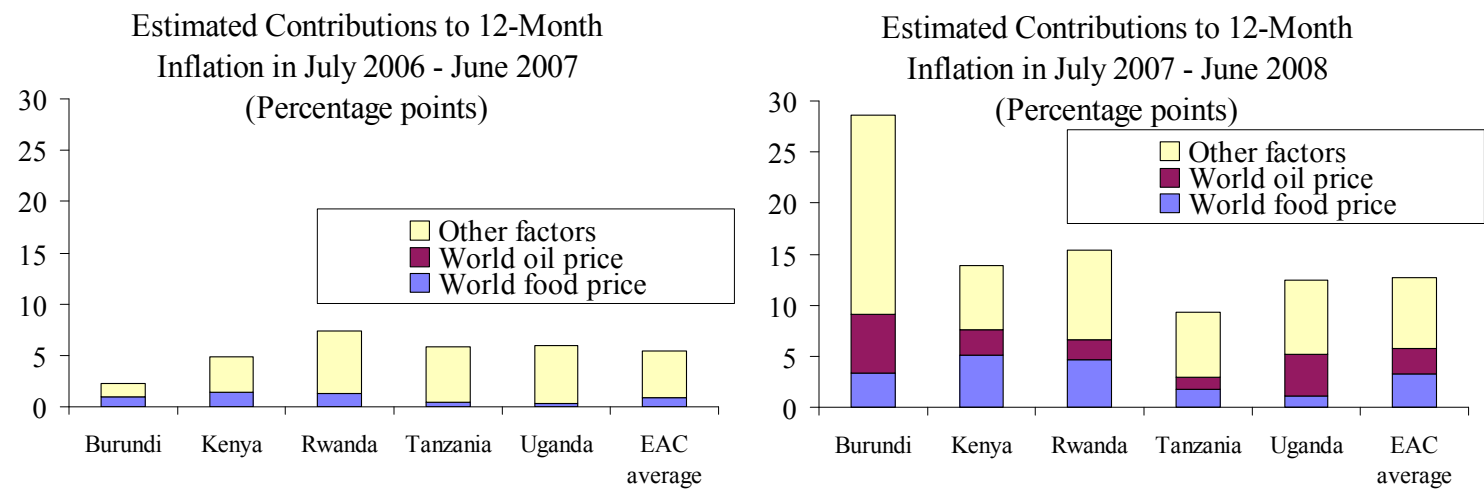

Source: WEO; and IMF staff projections.

Other factors, however, also seem to play an increasing role in all countries, except for Tanzania (Table 6, Figure 12). The political turmoil in Kenya (which led to an increase in transportation costs to all EAC countries except Tanzania), weather shocks to domestic supply in the food market, higher international prices of other imported products, and domestic fiscal and monetary policy shocks are all events that could explain the increasing contribution of "other factors" to inflation. It is also possible that the unusually pronounced and sustained increase in oil and food prices in recent years could have led to an increase in pass-through coefficients (a structural break). For example, the speed of adjustment of inflationary expectations may have increased after the recent sharp hike in oil and food prices, and the capacity of retailers to further squeeze their margins and reduce the passthrough from import prices may have reached its limit.

Econometrically disentangling the contribution of each of these other factors to inflation is beyond the scope of this paper. Quantifying the effect of Kenya's turmoil requires information on the impact of such turmoil on the cost of services at the Mombasa port as well as transportation costs from Mombasa to each EAC country (excluding Tanzania). Estimation of the impact of monetary policy on inflation would require identifying exogenous changes in monetary policy as well as the endogenous response of policy to other shocks in the economy (such as changes in the fiscal stance). These exogenous and endogenous changes in policy cannot be inferred from data on monetary aggregates alone and can only be derived from a more detailed modeling of the monetary policy framework, which is beyond the scope of this paper. Similarly, identifying shocks to fiscal policy requires identifying changes in the fiscal stance that are independent of price and GDP dynamics. More detailed information on tax rates and autonomous government expenditure would be needed. 
Figure 12. Contribution to Inflation of World Food and Oil Prices and Other (January 2006 - October 2008)
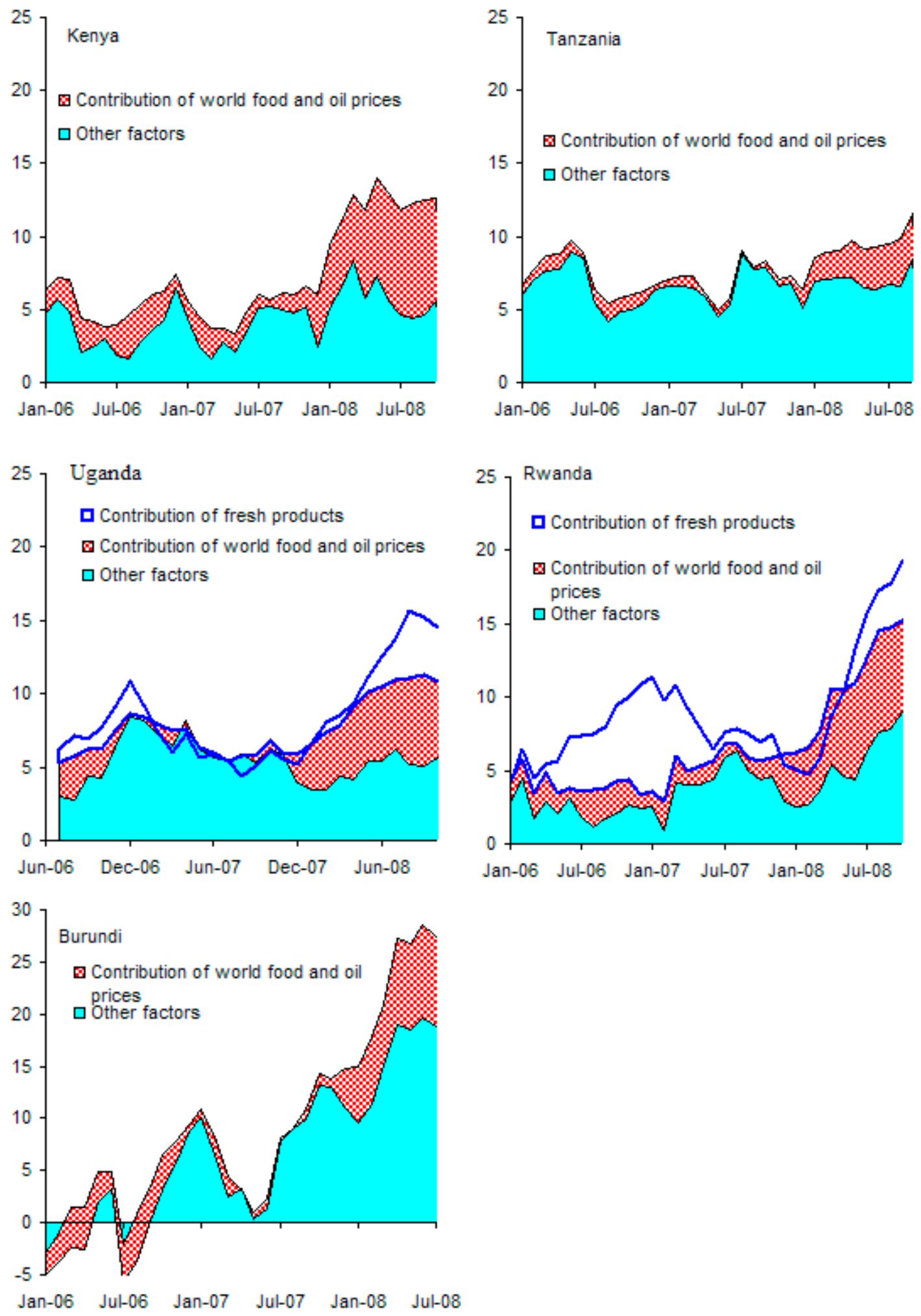

Source: Country authorities; IMF staff estimates. 
Nevertheless, qualitative analysis can be used to explain the rising contribution of other factors to inflation (Figure 12). For example, for Rwanda and Uganda, the contribution of fresh foods inflation can also be singled out. ${ }^{7}$ Fresh food price increases made a sizable contribution to inflation over the last year, partly reflecting domestic production cycles, but also thriving regional trade fueled by higher demand in neighboring non-EAC countries. Separating the impact of fresh foods reduces the impact of other (policy driven) factors more in Uganda than in Rwanda. This is consistent with scaling up of aid and spending in Rwanda in 2007 and a fairly tight fiscal stance maintained in Uganda during the same period.

\section{Is There Scope for Domestic Policies to Mitigate the Pass-Through? FIRST- AND SECOND-ROUND EFFECTS}

The pass-through coefficients of world oil and food prices to inflation, estimated in the previous section, include both first- and second-round effects. Typical policy advice in the face of an exogenous shock to import prices has been to accommodate first-round effects on domestic prices but prevent an increase in the general price level if it reflects second-round effects. It is therefore important to distinguish between the first- and second-round effects. In this section we define and calculate these effects for each country. ${ }^{8}$

First-round effects refer to both the direct impact on the CPI (and correspond to the weight of imported food and fuel in the CPI basket) and the indirect effect on consumer prices from the use of oil and food as intermediate inputs in the production of local goods ${ }^{9}$. These effects are calculated in the following way:

- $\quad$ The first-round direct effect is given by the estimated pass-through from world food and oil prices to domestic food and transportation prices (Table 3, lines 1 and 6) multiplied by the weight of these items in the CPI basket.

- The indirect effect is calculated by multiplying the following elements: (i) the estimated pass-through from world food and oil prices to domestic food and

\footnotetext{
${ }^{7}$ Data on prices of fresh foods are not readily available for the rest of EAC countries.

${ }^{8}$ Burundi has been excluded from the analysis in this section. As shown in Table 5, estimates for Burundi point to a very high direct first-round pass-through. The direct pass-through is actually higher than the overall passthrough, which would imply negative second-round effects. Given the relatively high inflation that has characterized this country, such result seems implausible.

${ }^{9}$ The definitions of the first- and second-round effects of the world food and oil prices on domestic inflation draw on definitions from the Fall 2008 Regional Economic Outlook: Sub-Saharan Africa, Box 1.4. "How Should Monetary Policy Respond to Supply Shocks?”
} 
transportation prices; (ii) the food and transportation content in consumption goods other than food and fuel, as estimated in the country's input-output matrix ${ }^{10,11}$; and (iii) the weight of these other goods in the consumption basket.

Second-round effects_-often resulting from increasing inflation expectations or from pressures to prevent erosion of real wages when inflation rises - can be defined as any additional increases in the price level beyond what can be explained by first-round effects. Specifically, we calculate the second-round effect as the difference between the total passthrough to headline inflation (Table 3 ) and the first-round effects.

Table 7 shows the contribution of first- and second-round effects to headline inflation for each EAC country. On average, first-round effects account for over three percentage points of the total contribution of world oil and food prices to 12-month inflation in June 2008. The share of first-round effects appears to be substantially higher in Kenya and Rwanda (70-75 percent of the total pass-through) than in Uganda and Tanzania (14-34 percent of the total pass-through), where it reflects a low estimated pass-through coefficient from world oil and food prices to domestic transportation and food prices (Table 5, lines 1 and 6). ${ }^{12}$ The low food price pass-through may be the result of high volatility of domestic food prices due to domestic supply shocks. The low fuel price pass-through may reflect variable profit margins for oil importers or regulation of transportation fees.

All factors of inflation - first- and second-round pass-through effects and factors unrelated to world oil and food prices - have increased over time. The rising first-round effect is simply a reflection of rising input prices and, given existing price rigidities, is to a large extent unavoidable. At the same time, second-round effects also played a significant role during the sample period, indicating that there may be some scope for domestic policies to mitigate inflationary pressures. However, such policy implications must be interpreted with caution given that methodological and data limitations lead to uncertainty about the true share of second-round effects in the overall pass-through coefficient. For example, to the extent that

10 This calculation uses the input-output matrix for Uganda ("Input/Output Tables for Uganda-1989 and 1992; Statistics Department of Ministry of Finance and Economic Planning (1995)”). Because a similar input-output matrix is not available for other EAC countries, we assume that they have the same cost structure as Uganda. To evaluate the sensitivity of the results to a different cost structure, we also used the structure implied by an inputoutput matrix developed for South Africa. The results remained broadly unchanged.

${ }^{11}$ The indirect first-round effects may now be stronger than implied by Uganda's 1992 input-output matrix to the extent that the economy may now use fuel and energy more intensively in its production processes than it did 15 years ago.

${ }^{12}$ For Uganda, the weight of food in the CPI basket is significantly lower than in the other EAC countries, which also helps explain its limited first-round effects from international food prices on inflation. 
the input-output matrix of Uganda - used as a basis in the calculations of all EAC countries - does not completely capture all the first-round effects in each country, secondround estimates will be overestimated, as the latter are obtained as a residual. For the same reason, factors that lead to an overestimation of the overall pass-through coefficient, but are unrelated to international food and fuel prices, are also likely to lead to an overestimation of second-round effects.

Table 7. Contribution of World Oil and Food Prices to 12-Month Inflation and First- and Second-round Effects Decomposition

\begin{tabular}{|c|c|c|c|c|c|}
\hline & Kenya & Rwanda & Tanzania & Uganda & EAC excl. Burundi \\
\hline \multicolumn{6}{|c|}{ July 2007-June 2008} \\
\hline 12-month inflation (observed) & 13.9 & 15.4 & 9.3 & 12.5 & 12.1 \\
\hline Estimated contribution of world oil and food prices & 7.6 & 6.6 & 3.0 & 5.2 & 5.6 \\
\hline Estimated first-round effects & 5.5 & 4.7 & 1.0 & 0.7 & 3.2 \\
\hline Direct first-round effects & 5.2 & 4.4 & 0.9 & 0.6 & 3.0 \\
\hline Indirect first-round effects & 0.4 & 0.3 & 0.1 & 0.1 & 0.2 \\
\hline Estimated second-round effects & 2.0 & 2.0 & 2.0 & 4.5 & 2.4 \\
\hline Other factors & 6.3 & 8.7 & 6.3 & 7.3 & 6.6 \\
\hline \multicolumn{6}{|c|}{ July 2006-June 2007} \\
\hline 12-month inflation (observed) & 4.8 & 7.3 & 5.9 & 5.9 & 5.4 \\
\hline Estimated contribution of world oil and food prices & 1.4 & 1.3 & 0.5 & 0.3 & 0.9 \\
\hline Estimated first-round effects & 1.4 & 1.2 & 0.2 & 0.1 & 0.8 \\
\hline Direct first-round effects & 1.3 & 1.1 & 0.2 & 0.1 & 0.7 \\
\hline Indirect first-round effects & 0.1 & 0.1 & 0.0 & 0.0 & 0.0 \\
\hline Estimated second-round effects & 0.0 & 0.1 & 0.3 & 0.2 & 0.1 \\
\hline Other factors & 3.4 & 6.0 & 5.4 & 5.6 & 4.5 \\
\hline \multicolumn{6}{|c|}{ Change 2006/07 - 2007/08 } \\
\hline 12-month inflation (observed) & 9.1 & 8.1 & 3.4 & 6.6 & 6.7 \\
\hline Estimated contribution of world oil and food prices & 6.2 & 5.4 & 2.5 & 4.9 & 4.7 \\
\hline Estimated first-round effects & 4.2 & 3.5 & 0.8 & 0.6 & 2.4 \\
\hline Direct first-round effects & 3.8 & 3.2 & 0.7 & 0.5 & 2.2 \\
\hline Indirect first-round effects & 0.3 & 0.2 & 0.1 & 0.1 & 0.2 \\
\hline Estimated second-round effects & 2.0 & 1.9 & 1.7 & 4.3 & 2.3 \\
\hline Other factors & 2.9 & 2.7 & 0.9 & 1.7 & 2.0 \\
\hline
\end{tabular}

Source: Staff estimates.

\section{Conclusions}

This paper confirms that world commodity price shocks have added to inflationary pressures in the EAC countries in 2008. A number of factors may have mitigated the strength of the pass-through in individual countries, such as domestic economic policies, domestic cost structure, market fragmentation, government regulatory policies (including taxation), and market intervention.

In all the EAC countries except Burundi, the pass-through from the world food and fuel prices explains more than two-thirds of the increase in inflation through June 2008, of which second-round effects seem to constitute a substantial share. To prevent these shocks from 
translating into permanently higher inflation, monetary policies in the EAC countries need to limit second round pass-through effects and anchor inflation expectations.

The negative impact of the world food and oil price shock peaked in 2008 and will most likely reverse in 2009. According to the current projections, the world food and oil prices will decline substantially in 2009. As a result, their declining prices can subtract several percentage points from the headline inflation in EAC countries. This should help reduce inflation in the region. 


\section{References}

Barnichon, Régis, and Shanaka J. Peiris, 2007, "Sources of Inflation in Sub-Saharan Africa," IMF Working Paper No. 07/32 (Washington: International Monetary Fund).

Blanchard, Olivier, and Jordi Galí, 2007, "The Macroeconomic Effects of Oil Shocks: Why Are the 2000s So Different from the 1970s?” NBER Working Paper No. 13368 (Cambridge, Massachusetts: National Bureau of Economic Research).

Chen, Shiu-Sheng, 2008, “Oil Price Pass-Through into Inflation,” Working Paper (Taipei: Taiwan National University, Department of Economics).

De Gregorio, Jose, Oscar Landerretche, and Christopher Neilson, 2007, “Another Passthrough Bites the Dust? Oil Prices and Inflation," Working Paper (Santiago: Central Bank of Chile).

Hooker, Mark A., 2002, "Are Oil Shocks Inflationary? Asymmetric and Nonlinear Specifications Versus Changes in Regime," Journal of Money, Credit, and Banking, Vol. 34, No. 2, pp. 540-61.

International Monetary Fund, 2008a, Regional Economic Outlook: Sub-Saharan Africa (Washington: International Monetary Fund). , 2008b, Regional Economic Outlook: Western Hemisphere (Washington: International Monetary Fund).

, 2008c, World Economic Outlook (Washington: International Monetary Fund).

Jakab, Zoltán M, and Mihály András Kovács, 2003, “Explaining the Exchange Rate PassThrough in Hungary: Simulations with the NIGEM Model," Working Paper (Budapest: National Bank of Hungary).

Kilian, Lutz, and Silvia Goncalves, 2007, “Asymptotic and Bootstrap Inference for AR(infinity) Processes with Conditional Heteroskedasticity," Econometric Reviews, Vol. 26, No. 6, pp. 609-41.

Kovanen, Arto, 2004, “Zimbabwe: A Quest for a Nominal Anchor,” IMF Working Paper No. 04/130 (Washington: International Monetary Fund).

Mwase, Nkunde, 2006, “An Empirical Investigation of the Exchange Rate Pass-Through to Inflation in Tanzania,” IMF Working Paper No. 06/150 (Washington: International Monetary Fund). 


\section{Appendix A. Literature Survey}

The econometric methodology for the pass-through analysis has been developed mostly for estimating the impact of the exchange rate. Many studies employed vector autoregressive (VAR) models of inflation or cointegration techniques (Barnichon and Peiris, 2007; Kovanen, 2004; Mwase, 2006). Studies relying on VARs usually estimated pass-through using standard impulse response functions, most typically with Cholesky decomposition of factors. More sophisticated approaches involve estimating a structural VAR (SVAR) to trace the chain of shocks that ultimately affect CPI (Blanchard and Galí, 2007). Another strand of literature relies on inflation models derived from the Philips curve equation (Hooker, 2002; De Gregorio, Landerretche, and Neilson, 2007). In these models, the pass-through is usually estimated as the sum of coefficients for explanatory variables in the equation. It is also possible to use macromodels to simulate the impact of various factors on inflation (Jakab and Kovács, 2003). Given the similarities of the inflationary impact of the exchange rate and world commodity prices, the same modeling frameworks, particularly those based on VAR approaches, can be used to estimate the pass-through of world food and oil prices to inflation.

Recent studies of pass-through from world food and oil prices to inflation produced a wide range of estimates. ${ }^{13}$ The study for 10 countries of Central and South Latin America (IMF, 2008b, Chapter III) reported the average pass-through of 0.006 for world oil and 0.03 for world food prices. Pass-through values varied considerably, and for two countries the reported coefficients for oil had an unexpected negative sign. In a study covering 19 industrial countries, Shiu-Sheng Chen (2008) reported average pass-through from oil prices to inflation of about 0.009 in the short run (within one quarter) and about 0.10 in the long run. The strength of the pass-through varied widely by country and appeared to be correlated with the volumes of oil imports. An influential study for the U.S. (Blanchard and Galí, 2007) reported a pass-through from oil price to inflation of about 0.025 in the post-1984 periodless than half the pass-through estimated for the 1970 s.

The October 2008 World Economic Outlook (WEO; IMF, 2008c) also documents the strong contribution of world food and fuel prices to inflation. It reported that in emerging economies the average pass-through from world food prices (measured in local currency) to local prices was about 0.16 and for oil it was about 0.12 . It also estimated that the pass-through from local food to core inflation was as high as 0.5 , while for fuel it seemed almost negligible. The results reportedly varied considerably by country. However, the WEO stopped short of calculating total pass-through to headline inflation and did not strip out the impact of the exchange rate (IMF, 2008c).

\footnotetext{
${ }^{13}$ The figures reported measure the contribution to headline inflation of a 1 percent increase in a commodity's price.
} 


\section{Appendix B. Methodology of the Econometric Analysis}

\section{VAR model with world food and oil prices as exogenous variables ${ }^{14}$}

To estimate the pass-through from world food and oil prices, we constructed vector autoregressive (VAR) models of inflation for each EAC country. This model incorporated the consumer price index (CPI), money supply, real GDP, exchange rate, and world food and oil price indices. To account for the fact that EAC countries are price-takers in the international oil and food markets, the equations for food and oil prices are estimated as an exogenous block, i.e., independent of domestic variables. Formally, the following econometric model was estimated:

$$
\left[\begin{array}{l}
x_{t} \\
y_{t}
\end{array}\right]=\left[\begin{array}{cc}
A(L) & 0 \\
B(L) & C(L)
\end{array}\right]\left[\begin{array}{l}
x_{t} \\
y_{t}
\end{array}\right]+\left[\begin{array}{l}
v_{1, t} \\
v_{2, t}
\end{array}\right]
$$

where $x_{t}$ is the vector of international prices for oil and food and $y_{t}$ is a vector of domestic variables: domestic inflation, exchange rate depreciation, growth rate of a monetary aggregate, and real GDP growth. $\mathrm{A}(\mathrm{L}), \mathrm{B}(\mathrm{L})$, and $\mathrm{C}(\mathrm{L})$ are coefficient matrices with lag operators, and $\left[\begin{array}{l}v_{1 t} \\ v_{2 t}\end{array}\right]$ is a vector of disturbances.

To estimate the pass-through, we simulated the cumulative response of domestic inflation to an independent shock to either world prices of oil or food over a 12 -month period. ${ }^{15}$ Using a bootstrap procedure, ${ }^{16}$ we generated confidence bands for the pass-through estimates for each EAC country.

\footnotetext{
${ }^{14}$ A model with all variables treated as endogenous was also estimated, yielding similar results. This model captured the interaction between world oil and food prices, but also implied that domestic variables in EAC countries have an impact on international prices (the estimates of the latter were relatively small). We also tested several alternative model specifications. For instance, we estimated VAR models on variables in levels rather than in first differences. However, the results did not seem as statistically robust as those of the main models described above, so they are not reported.

${ }^{15}$ The cumulative response of inflation to a one time shock typically converged over a much shorter period.

16 The bootstrap procedure allows us to generate a frequency distribution for the pass-through coefficient. The procedure generates a large number of random subsamples. For each of these, a VAR and a pass-through coefficient is estimated (Kilian and Goncalves, 2007).
} 


\section{Set of three VAR models for each country}

To test the robustness of the estimates and study the pass-through channels, we estimated a set of three VAR models for each EAC country. We started by decomposing the CPI into its food, transport, and core inflation components. The first VAR included local food price index, money supply, real GDP, exchange rate, world food price index, and world oil price. The second VAR substituted the local transport (or fuel) price index for the food price index. The last VAR included local food and transport price indices, local core inflation, money supply, real GDP, and the exchange rate. With this set of VARs it became possible to estimate the pass-through from world food and oil prices into local food and transport price indices and from them into core inflation. The pass-through into headline inflation could be estimated using the weights of food, transport, and core inflation in the CPI basket. To ensure robustness, we estimated this set of VARs for two cases: when world food and oil prices were treated as endogenous and when they were included as exogenous variables.

This approach explicitly recognizes that the first-round effects of world fuel and food prices may pass into inflation through different channels. It starts with the impact on domestic food and fuel prices. To the extent that these goods are in the CPI basket, they have a direct effect on CPI. Next, domestic fuel prices contribute to the cost structure and final retail prices of other goods in the CPI basket, partly through higher transportation costs within the country.

\section{VECM model}

Finally, we estimated a vector error correction model (VECM) of inflation for Tanzania. ${ }^{17}$ Standard tests indicated that headline inflation in Tanzania is cointegrated with world food and oil prices and the exchange rate. The tests also confirmed the cointegration for the food price index but not for transport prices. Hence, we constructed a VECM model of headline inflation with one cointegration and a model of the food price index with the same specification of the cointegrating equation.

\section{Consistency and significance of estimates}

\footnotetext{
${ }^{17}$ We attempted to construct VECM models for all other EAC countries, but could not obtain robust results. This may be due to higher volatility of the main variables, which made deviations from estimated long-term equilibrium too large. This confirmed that VAR models are appropriate for studying inflation in majority of the EAC countries.
} 
All the models described produced relatively consistent estimates of the pass-through from world food and oil prices. The results obtained from various model specifications for Kenya, Rwanda, and Uganda were particularly close or even identical. The results for Burundi and Tanzania were more dispersed. The estimates from one VAR model for each EAC country with world food and oil price included as exogenous variables were considered the most statistically robust for all EAC countries except Tanzania. For Tanzania, the confidence tests found the results to have very low significance, which prompted us to rely on the results of the VECM model. Table A1 summarizes the results obtained from various model specifications for all EAC countries.

To confirm the robustness of the VAR results, we estimated their statistical significance and found high significance for the Kenya and Rwanda results and a mixed outcome for Burundi and Uganda, where only the oil pass-through estimates had high significance. For Tanzania, the tests found the results to have very low statistical significance, particularly the estimated pass-through coefficient for oil that had an unexpected negative sign. This led to the conclusion that the VAR specifications selected may be inappropriate for Tanzania.

\section{Impact world food and fuel prices on money supply and the exchange rate}

To complete the analysis, we estimated the pass-through from world food and oil prices to money and the exchange rate. For all EAC countries except Tanzania, we obtained these estimates from VAR models by simulating the Cholesky response of the exchange rate and monetary aggregates to a shock to either world oil or food prices. For Tanzania, we estimated the pass-through using the VECM model (Table A2). The results indicate that the food price shock led to a strong increase in money supply, which was partially offset by the currency appreciation. The pass-through of oil prices to money was relatively modest and was accompanied by a currency depreciation. 
Table A1. Summary of Pass-through Estimates Obtained from Various Model Specifications

(Percentage points ${ }^{1}$ )

\begin{tabular}{|c|c|c|c|c|c|c|c|}
\hline & Burundi & Kenya & Rwanda & Tanzania & Uganda & \multicolumn{2}{|c|}{ 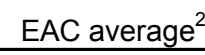 } \\
\hline \multicolumn{8}{|c|}{ One VAR model for each country, all variables included as endogenous } \\
\hline World food price & 0.69 & 1.13 & 1.29 & 0.53 & 0.34 & & 0.79 \\
\hline World oil price & 0.86 & 0.52 & 0.44 & -0.18 & 0.63 & & 0.34 \\
\hline \multicolumn{8}{|c|}{ One VAR model for each country, world food and oil prices included as exogenous variables } \\
\hline World food price & 0.75 & $1.11^{* *}$ & 1.03 * & 0.43 & 0.25 & & 0.73 \\
\hline World oil price & $0.84^{* * *}$ & $0.37^{* * * *}$ & $0.29 * *$ & -0.12 & $0.59 * * * *$ & & 0.28 \\
\hline \multicolumn{8}{|c|}{ Set of three VAR models for each country, all variables included as endogenous } \\
\hline World food price & 1.31 & 1.18 & 1.25 & 0.20 & 0.23 & & 0.71 \\
\hline World oil price & 0.28 & 0.44 & 0.37 & 0.13 & 0.58 & & 0.37 \\
\hline \multicolumn{8}{|c|}{ Set of three VAR models for each country, world food and oil prices included as exogenous variables } \\
\hline World food price & 1.56 & 1.09 & 1.22 & 0.14 & 0.20 & & 0.65 \\
\hline World oil price & 0.24 & 0.25 & 0.19 & 0.03 & 0.55 & & 0.25 \\
\hline \multicolumn{8}{|c|}{ One VECM model, all variables included as endogenous (for Tanzania only) } \\
\hline World food price & & & & 0.38 & & & \\
\hline World oil price & & & & 0.18 & & & \\
\hline \multicolumn{8}{|c|}{ Range of estimates across model specifications } \\
\hline World food price, minimum & 0.69 & 1.09 & 1.03 & 0.14 & 0.20 & 0.65 & \\
\hline Maximum & 1.56 & 1.18 & 1.29 & 0.53 & 0.34 & & 0.79 \\
\hline World oil price, minimum & 0.24 & 0.25 & 0.19 & -0.18 & 0.55 & 0.25 & \\
\hline Maximum & 0.86 & 0.52 & 0.44 & 0.18 & 0.63 & & 0.37 \\
\hline
\end{tabular}

Source: IMF staff estimates.

${ }^{1}$ Contribution of 10 percent increase in each variable to the headline inflation.

${ }^{2}$ Calculated as weighted average, using the 2005 nominal GDP in US dollar terms as weights.

${ }^{* * * *}$ Indicates significance at 90 percent, ${ }^{* * *}$ significance at 80 percent, ${ }^{* *}$ significance at 70 percent,

* significance at 60 percent. Significance reported only for the case of one VAR model for each country, with world food and oil prices included as exogenous variables.

Table A2. Impact of the World Food and Fuel Prices on Money and Exchange Rate in EAC Countries. (Percentage points ${ }^{1}$ )

\begin{tabular}{llllrrr} 
& Burundi & Kenya & Rwanda & Tanzania & Uganda & EAC average $^{2}$ \\
\hline World food price & & & & & & \\
Money (cash in circulation) & $4.16^{* * * *}$ & $1.08^{* * *}$ & $3.15^{* * *}$ & $3.22^{3}$ & $1.75^{* * *}$ & 1.77 \\
Exchange rate ("-" - appreciation) & 0.21 & $-2.90^{* * * *}$ & -0.65 & $-2.57^{3}$ & $-2.91^{* * *}$ & -2.48 \\
World oil price & & & & & & \\
Money (cash in circulation) & $1.03^{* * * *}$ & $0.23^{*}$ & 0.31 & $0.91^{3}$ & -0.05 & 0.09 \\
Exchange rate ("-" - appreciation) & 0.04 & $0.90^{* * * *}$ & 0.25 & $-0.37^{3}$ & 0.34 & 0.59 \\
\hline
\end{tabular}

Source: IMF staff estimates.

${ }^{1}$ Contribution of 10 percent increase in each variable to the money expansion or exchange rate. For Tanzania, estimated using VECM model. For other countries, estimated using VAR model with world food and oil price as exogenous variables.

${ }^{2}$ Calculated as weighted average, using the 2005 nominal GDP in U.S. dollar terms as weights.

**** Indicates significance at 90 percent, ${ }^{* * *}$ significance at 80 percent,

${ }^{* *}$ Indicates significance at 70 percent, * significance at 60 percent.

${ }^{3}$ Statistical significance level not available. 